\title{
Poverty versus Food Security in India
}

\author{
B. Ramachandra*, N. Venkata Narayana** \\ *Lecturer in Economics, K.H. Government Degree College, Dharmavaram, Anantapur District Andhra Pradesh \\ **Lecturer in Economics, S.V.G.M. Government Degree College, Kalyanadurg, Anantapur District Andhra \\ Pradesh
}

Abstract: Poverty is a reflection of food insecurity. It has pursued mankind since times immemorial. The world is experienced with the consequences of poverty. It is the governments' responsibility to mitigate poverty through providing food security. Hence, the central and state governments in India have launched many poverty alleviating programmes

\section{Introduction:}

Mankind, from times immemorial, is facing poverty. The world countries even developed countries which are in high income group cannot escape from the grip of poverty, It is, therefore, not difficult to understand the degree of poverty in low income group countries. As per the World Bank report more than one billion people to-day live on less than $\$ 1$ per day. About 70 per cent of those people are women, and almost half of the population of sub Saharan Africa survives at that income level. We know that every 3.5 seconds, a child in the developing world dies due to poverty circumstances.

As per the ILO statement" working poverty has continued to decrease, but at a slower pace than before the crisis. There are still some 870 million workers living with their families on less than US \$2 per person per day, of which nearly 400 million are living in extreme poverty. A further 660 million workers are living just above the poverty line and are at high risk of falling back.

Poverty is not an economic phenomenon alone; it is a social phenomenon too. The world has well experienced with the consequences of poverty such as hunger, humiliation, unrest, deprivation of liberty, discrimination etc. To define Poverty is not an easy task. Poverty, in general, is defined as lack of consumption of food resulted from low income. It is, in fact, complex and multidimensional aspect.

Lalita kumary opined that "Poverty is a socio-economic phenomenon in which a section of society is unable to fulfil even its basic necessities of life. The minimum needs are food, clothing, housing, education and other basic minimum human needs. Humanity faces pains and miseries if it does not attain a subsistence level of such needs. It is generally agreed in this country that only who fail to reach a certain minimum consumption standard should be regarded as poor."

Professor Suresh D Tendulkar Committee has been appointed to estimate poverty in India. The committee has estimated rural poverty as 25.7 per cent, 13.7 as urban poverty and 21.9 per cent as overall poverty for 2011-2012.The committee recognized 269.3 millions of people are in below poverty line in the same period.

Food security has been the central attraction in the world for discursion. World Food summit which was held in 1974 in Rome stated that "the most basic problem of mankind: food security". Mere availability of food does not mean food security. The components which are essential to give complete meaning of Food security can be found in the definition that is given by Food and Agricultural Organisation. It defines food security as the situation when "all people, at all times, have physical, social and economic access to sufficient, safe and nutritious food that meets their dietary needs and food preferences for an active and healthy life".

Unfortunately the Earth is full of resources but, most of the world people especially the people in third world countries are in the grip of hunger due to insecurity of food. Jean Ziegler, a member of UN Human Rights Council's Advisory Committee rightly stated that "in a world overflowing with riches, it is an outrageous scandal that more than one billion people suffer from hunger and malnutrition and that ever year over 6 million children die of starvation and related causes".

\section{Need of food Security in India}

India is basically an Agrarian economy. Owing to low pace in urbanisation most of the population is still living in the rural area that is why it is said that India is living in her villages. It is inevitable that the growing population has to depend on agriculture for survival and it leads to poverty. The following tables $1 \& 2$ show the poverty in India 
Table No: 1(A)

Poverty in India (in percentage)

\begin{tabular}{|c|c|c|c|}
\hline year & Rural & Urban & Total \\
\hline $1973-74$ & 261.3 & 60.3 & 321.6 \\
\hline $1977-78$ & 264.3 & 67.7 & 332 \\
\hline $1987-88$ & 229.4 & 83.3 & 312.7 \\
\hline $2004-05$ & 326.3 & 80.8 & 407.1 \\
\hline $2011-12$ & 216.5 & 52.8 & 269.3 \\
\hline
\end{tabular}

Table No: 1(B) population in below Poverty line ( In millions )

\begin{tabular}{|c|c|c|c|}
\hline year & Rural & Urban & Total \\
\hline $1973-74$ & 56.4 & 49.2 & 54.9 \\
\hline $1977-78$ & 53.1 & 47.4 & 51.8 \\
\hline $1987-88$ & 39.1 & 40.1 & 39.3 \\
\hline $2004-05$ & 41.8 & 25.7 & 37.2 \\
\hline $2011-12$ & 25.7 & 13.7 & 21.9 \\
\hline
\end{tabular}

Source: Compiled from the Planning Commission (1993) \&Economic survey of India 2013-14

The table No: 1(A) shows that both Rural and Urban poverty moves downwards. From 2004-05 onwards the poverty was declined sharply in both areas. In Rural area poverty was declined from 41.8 per cent to 25.7 per cent and in Urban area it was declined from 25.7 to 13.7 per cent. Nobody can deny the fact of reduction in poverty in India, but the necessity to provide food security is visualised obviously in the table No: 1(B). Though the number of poor people was reduced at a great rate 2004-05 onwards, the number of people who were living below poverty line in both areas is not at considerable figure to neglect.

Food insecurity linkages with poverty, in fact, they are inseparable. Poverty can be measured in terms of calories of energy which is produced by intake of quality and quantity food. Therefore poverty is a reflection of food insecurity. Asian Development Bank reported that "Asia still is home to two- third of world's population across the globe, poverty is the single most common cause of food insecurity".

Table No:2(A)

Monthly per capita Expenditure (2004-05 prices)

\begin{tabular}{|c|c|c|c|}
\hline Year & Round & Rural & Urban \\
\hline $2004-05$ & 61 st & 558.78 & 1052.36 \\
\hline $2009-10$ & 66 th & 599.06 & 1200.01 \\
\hline $2011-12$ & 68 th & 703.42 & 1353.82 \\
\hline
\end{tabular}

Table No:2(B)

Monthly per capita Expenditure (current prices)

\begin{tabular}{|c|c|c|c|}
\hline Year & Round & Rural & Urban \\
\hline $2004-05$ & 61 st & 558.78 & 1052.36 \\
\hline $2009-10$ & 66 th & 927.7 & 1785.81 \\
\hline $2011-12$ & 68 th & 1278.94 & 2399.24 \\
\hline
\end{tabular}

Source: Economic Survey of India 2013-14

Monthly per capita Expenditure at constant prices (2004-05) and current prices is increasing Round to Round. It is shown clearly in Table No: 2(A) and 2(B). The table No: 2(B) is the witness for inflation. Per capita income in India is comparatively low even with neighbour Developing country Sri lanka. Hence, majority Indians are receiving low income due to deferent reasons.

India is still Food security is a fundamental right. In fact, the right has been incorporated in Article 21 that is Right to live, that has been guaranteed by the Indian constitution. It is pity to say that though food security has been safeguarded by the constitution, India had the highest child mortality rate worldwide in 2012 with 1.4 million children dying before reaching their fifth birthday. An analysis of National Family Health Survey (NFHS)-3 data showed that neonatal mortality among children born to mother with low Body Mass Index (BMI) was slightly higher than those with normal and it reported that severe anaemia was associated with 26 per cent higher neonatal and 16 per cent higher post-neonatal mortality rates. Therefore, Governments have to assure food security to the people.

\section{Dimensions of food Security:}

Availability, accessibility, properly utilisation and sustainability are the facet of Food Security. Enough food is available for the world's population as a whole. But there are disparities among the countries, with in the country, interstate and intra state due to climate, fertility, rain fall, technology and so on.

\section{Causes of poverty and food insecurity:}

4.1. Low Agricultural growth rate

India still is in the clutches of food insecurity as well as poverty due to the failure of five year plans in meeting the pace of Economic Development with the increasing requirements for the increasing population. The growth rate in the primary sector is gradually decline as Neglecting primary sector. 
Figure No: 1

Agricultural Growth rate

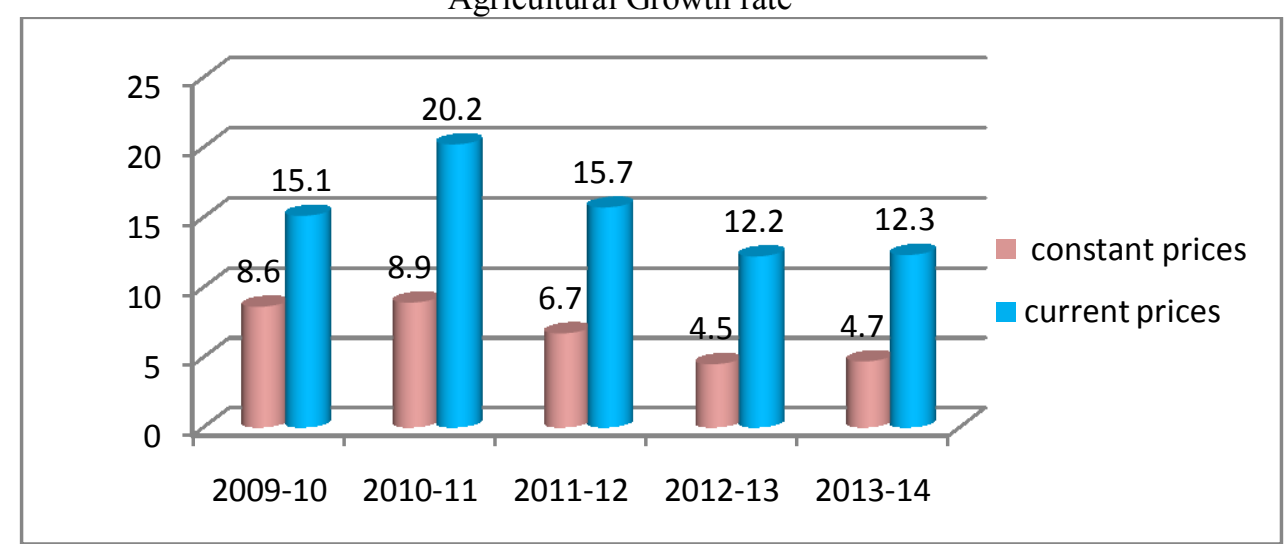

Source; Economic survey of India 2013-14

It is better to study the Growth rate of Agriculture at constant prices rather than current prices. The figure shows that the rate of growth was marginally increased in 2010-11 than the preceding year. Thereafter it was decreasing. Though it is increased in 2013-14, it is not considerable increment.

\subsection{Low productivity in Agriculture}

Low productivity in Agriculture is one of the main reasons for poverty and food insecurity in India. Economic Survey of India 2013-14 has recognised that the production in major crops is enhanced due to acreage rather than productivity.

\subsection{Poor irrigation facilities}

Indian agriculture is facing poor irrigation facilities. Majority of Agro lands especially in southern India are dry lands, hilly, rocky and sandy regions which are unsuitable for cultivation. Among them, though, some lands are useful for some extent. Cultivation in dry lands is completely depending on monsoons. Resulting of continuous failure of monsoons the Agricultural sector is unable to produce to meet the requirement of increasing population in India.

\subsection{Land fragmentation:}

Cultivable land in India has been declined to 182.57 million hectors in 2005-06 from 185.09 million hectors in 1980-81. ARCAS, 2010 reported that in India 63 per cent of holdings are below 1 ha accounting for 19 per cent of the operated area while over 86 per cent of holding are less than 2 ha account for nearly 40 per cent operated area. Average cultivable land has shrunk from 1.69 hectors in 1985-86 to 1.1 to hectors in 2010-11.

\subsection{Investment pattern:}

Many research studies emphasise the need of adopting modern technology in Agriculture which enhance the acreage. Large scale of investment is required for introducing modernized technology in Agriculture. Public and private investment in Agriculture is not supporting at enough scale and at the same time more concentration has paid on heavy industries which has long period gestation are some of the causes that leads to imbalance between the demand for and supply of food grains.

\subsection{Commercialisation in Agriculture:}

Invade of commercialisation on Agriculture through the advent of liberalisation in this sector has led to minimising food crops in India. Though the production in Agriculture increases, the pace of increment in production of the sector is much lower than the pace of demand for food grains.

\section{Measures for food security:}

The central and state governments in India have made different efforts for reducing poverty and food insecurity through implementation of employment generating programmes. Some programmes are discussed below.

\subsection{Community Development programme}

The community development programme was launched by the first president of India Dr Rajendra Prasad on October 2, 1952, with the objective of bringing about multi-purpose rural development with people participationUp to April 1977, the programme covered more than five thousand blocks all over the country. 
5.2. Intensive Agriculture Development programme (IADP)

On the recommendations of Fort foundation committee the Government of India implemented in the selected Districts in various states in the country in 1960-61. The result of IADP programme has paved the way for the Green revolution in agriculture loans, seeds, fertilizer tools to the farmers in the selected Districts.

\subsection{Rural Man Power Programme (RMP)}

In the ending of 1960-61 the Rural Man Power Programme (RMP) was taken up in 32 community development blocks as on a pilot project with the objective of providing employment of 100 days for at least 25 million people by the end of the third five year plan, especially in areas exposed to pronounced seasonal unemployment and under employment. It covered 1000 Community Development blocks and it provided 137 million Man-days of employment until the year 1968-69 in which the programme was terminated.

\subsection{Small farmers Development Agency (SFDA)}

The main objective of the scheme was to provide credit to the small farmers to enable them to make use of the latest technology to practice intensive farming and diversify their activities. Up to 1980 the Agency identified 16 million persons from the targeted group for assistance.

\subsection{Marginal Farmers and Agricultural Labourers' Agency (MFALA)}

One of the objectives of Fourth five year plan (1969-74) was to assist to the targeted famers, agricultural labourers and those in subsidiary occupations like dairy, poultry, fishery, pig-rearing, horticultural operations, etc.

\subsection{Crash Scheme for Rural Employment}

The Crash Scheme for Rural Development (CSRE) was launched to provide additional employment to the rural unemployed in the fourth five year plan. It had a twofold purpose. Firstly, the programme would generate employment on an average of 100 persons in every block or about 1000 persons in each district in rural development works continuously over a working season of 10 months in a year. Secondly, each project was to produce work or asset of durable nature in consonance with the local development plans.

\subsection{Pilot Intensive Rural Employment Project (PIREP, 1972)}

The programme was launched as a pilot project in November, 1972 for finding answer to the rural unemployment problem in India. The projects were taken up as research and action projects. The project aimed at providing employment to one third of the unemployed persons every year and thus covering all unemployed persons in selected blocks in the country situated in different economic and ecologic conditions.

\subsection{Drought-Prone Area Programme (DPAP)}

The Drought- Prone Area Programme (DPAP) was launched in 1973-74 in some selected Drought Prone Areas of the country. The main objective of the programme was reestablishment of the environment balance in these areas by promoting balanced development of land, water, and other natural resources.

\subsection{Twenty point Economic programme (1975)}

This programme was conceived by the late Prime Minister Smt. Indira Gandhi and launched on $1^{\text {st }}$ July 1975 Under the slogan of "Garibi Hatao" (Remove Poverty),. The programme outlined the basic task of improving the living condition of the economically weaker section of the society especially of rural poor. In the light of emerging a new socio-economic environment, the programme was redefined, revitalized and announced to the nation on $14^{\text {th }}$ January 1982 and again on $20^{\text {th }}$ August 1986 as per the direction given by the Prime Minister Sri Rajiv Gandhi and implemented since $1^{\text {st }}$ April 1987 along with the Annual plan 1987-88. This programme helped millions of poor by providing them with self-employment and basic amenities of life.

\subsection{Food for Work Programme (FWP)}

National food for work programme was launched in 1977-78, with three fold objectives creation of additional employment opportunities in rural areas, better maintenance of public works and utilization of surplus food grain stocks. Owing to various constrains inherent in the scheme as originally formulated, it has been modified subsequently to include all kinds of works. The programme was later renamed as National Rural Employment Programme (NREP) in 1980.

\subsection{Integrated Rural Development programme (IRDP)}

Integrated Rural Development Programme was initially launched in 2300 blocks in 1978-79, further, it was extended all over the country as a flag ship programme for eradicating poverty, on $2^{\text {nd }}$ October 1980 and 
was continued up to April 1999. In each block 600 poor families were to be assisted. For each block a uniform allocation of Rs. 35 lakhs was allocated. This was shared between the centre and the states on a 50-50 basis. Since beginning of the scheme till1998-1999, 53.5 million families benefitted under this scheme at the expenditure of Rs 13700 cores. The scheme along with other schemes namely TRYSEM, DWCRA, SITRA, Ganga Kalyan Yojana and MWS were merged into Swarna Jayanti Gram Swarojgar Yojana on $2^{\text {nd }}$ April 1999.

\subsection{Training of Rural Youth for Self-Employment (TRYSEM)}

TRYSEM was started on the independence day of 1979, as a central sponsored scheme. Under the scheme 40 youth were to be given training each year, covering 2 lakh youth in the country every year. After training they were provided financial assistance. The programme was merged into Swarnajayanti Gram Swarojgar Yojana in 1999.

\subsection{National Rural Employment Programme (NREP, 1980)}

The programme was introduced in October 1980 with the objectives of (i) Generation of wage employment opportunities, (ii) Creation of community assets, and (iii) Improvement of nutritional states of rural poor. To improve the effectiveness of the programme, it was combined with RLEGP in 1989 and renamed as Jawahar Rojgar Yojana.

\subsection{Rural Landless Employment Guaranty Programme (RLEGP)}

The RLEGP programme was started on $15^{\text {th }}$ of August, 1983, as a central sponsored programme with the objectives of creating employment opportunities, construction of the projects and improving rural life. The resources are allocated to the State/Union Territory on the basis of determined standards, in which 50 per cent weightage is given to the cultivators and marginal farmers on basis of their number and the remaining 50 per cent weightage is given on the basis of poverty. Under this programme wages of laboreres were given according to the Minimum Wages Act. Out of the total expenditure 10 percent had been planned for schedule casteand schedule tribes.

\subsection{Indira Awaas Yojana (IAY, 1985)}

The programme Indira Awas Yojana has been implemented since 1985. The main objective of this programme was to build houses for schedule caste and schedule tribes; free bonded labourers as also non schedule caste and schedule tribe rural poor who were residing below poverty line by providing them grants-inaid.

\subsection{Jawahar Rojgaar Yojana (JRY)}

In the last year of the Seventh plan, a broad rural employment programme named Jawahar Rojgar Yojana (JRY) was launched on the $1^{\text {st }}$ April, 1989. Since 1993-94, the JRY was implemented in three phases.JRY was one of the major wage employment programmes. It was implemented in all the villages of the country through the panchayat Raj Institutions. It contributed to a great extent in creating durable rural infrastructure which has a critical importance in the development of village economy thereby improving the standards of living of the rural poor.

\subsection{Employment Assurance Scheme (EAS, 1993)}

The EAS was started on $2^{\text {nd }}$ October in 1993 in 1,778 development blocks in the rural areas of 261 districts. During 1994-95, this scheme was implemented in 697 development blocks of Drought Prone Area Programme (DPAP) and Desert Development Programme (DDP) too.

The prime objective of the programme was to provide profitable employment not less than 100 days to every villager who is desirous of taking employment, between 18 to 60 years during the lean agriculture season. The second objective of the programme was to create economic infrastructure and community projects for creating sufficient employment and development activities.

This programme was reorganized from April 1st, 1999 and it was made the only centrally sponsored wage employment programme on a cost sharing ratio 75:25 (earlier this was 80:20). This central financial assistance was provided directly to the District Rural Development Agencies.

5.18. Rural Employment Generation Programme (REGP, 1995)

The REGP programme was launched in 1995. The prime objective of the programme was creating selfemployment opportunities in the rural areas and small towns. It was being implemented by the Khadi and Village Industries Commission (KVIC). Under this programme entrepreneurs could establish village industries by availing of margin money assistance from the KVIC and bank loans, for projects with a maximum cost of Rs 25 lakh. 


\subsection{Jawahar Gram Samridhi Yojana (JGSY)}

JGSY was started on the $1^{\text {st }}$ April 1999 to ensure development of rural infrastructure at the village level by restructuring the Jawahar Rojgar Yojana. The prime objective of the programme was creation of demand driven community village infrastructure including durable assets at village level that enable the poor to increase the opportunities for sustained employment. The second objective was generation of wage employment for unemployed poor in the rural areas.

\subsection{Mahatma Gandhi National Rural Employment Guarantee Act}

The programme has come into force through enactment; it was launched on February $2^{\text {nd }}$ in 2006. The programme has been renamed and amended as "Mahatma Gandhi National Rural Employment Guarantee Act" on $2^{\text {nd }}$ October in 2009. The main objective of MGNREGS is creating of at least 100 man days of employment. The rising demand for labour helps the poor to improve their standard of living. Income support from the programme enables the bargaining capacity of the unskilled labourers to some extent in agriculture, construction and other sectors in both rural and urban areas.

\subsection{Food Security Act 2013}

Through this Act $5 \mathrm{Kgs}$ of food grains will be provided for every eligible person at highly subsidised rate through public distribution system. It covers 75 per cent of rural people and 50 per cent of urban people.

\section{Conclusion}

All employment generated programmes that have been provided by central and state governments, are also food security programmes too. Though some bottlenecks are there in those programmes, they can mitigate poverty and food insecurity. But they should be made effective through plugging the bottlenecks.

\section{Recommendations suggested}

1. The governments have to make proper strategies for increasing the supply of food grains in the market rather than in fair price shops where food grains are provided at highly subsidizes rates. If the governments continue it for a long period it will become big financial burden to the governments.

2. RBI's quantitative measures are not suitable for low income countries because the increasing inflation is being occurred not due to more purchasing power. This is being occurred due to unmatched supply of goods with the demand. RBI's measures are suppressing the demand. It doesn't mean control inflation because it squeezing the purchasing power of especially poor people. Hence it is better to increase supply of food grains. Not only that, food grains must be at accessible rates.

3. It is however, to eradicate poverty which is a reflection of food insecurity the governments have to concentrate on the programmes that enhancing peoples' purchasing capacity in long period rather than continuing welfare programmes which make the people lazy in addition to take those measures which increases the availability of food grains in the market as well as to the individuals.

4. The governments should plug up the leakages like corruption for making the programmes effective.

5. Complete irrigation projects as early as possible.

6. Governments should take necessary measures for increasing public and private investment in Agriculture.

7. Concentrate investment on short term gestations.

8. Government should take necessary measure to encourage farmers to implement modern technology in Agricultural farming

9. Governments should take necessary measure for restoration and conservation of water, soil fertility,

10. Encourage farmers to use hazardless genetically modified seed.

[1]. Chronic Poverty Report 2008-09.

\section{References}

[2]. End poverty.org

[3]. Lalita kumari, Poverty Eradication in India:AStudy of National policies, Plans and programmes. Research World.com. A Journal of Arts, Science and commerce, Vol-I.Issue-2, April, 2013.

[4]. Search ilo.org

[5]. Food and Agricultural organisation2002

[6]. Praveen kumar, Kurukshetra, Vol 62, No. 1 Nov 2013

[7]. Food Security and Poverty in Asia and the Pacific,April 2012 